\title{
Plant diversity of Absheron peninsula
}

\author{
Alexander S. Zernov ${ }^{1}$ \\ Lomonosov Moscow State University, Faculty of Biology \\ Leninskie Gory, 1-12, Moscow, 119991, Russia \\ Shahla N. Mirzayeva \\ Institute of Botany, Azerbaijan National Academy of Sciences, \\ Badamdar 40, Baku, AZ1004, Azerbaijan
}

Abstract: In this article, we discuss the results of studying the flora of the Absheron Peninsula. The dynamics of the species composition over the past 70 years is considered. We were unable to find 206 species in the habitats previously recorded by Karyagin in 1952. We included 678 species in the list of flora of the Absheron Peninsula, of which 599 species were classified as native flora. In accordance with the direction of the dynamics of their habitats, we distinguish five groups of native flora species: Extinct (not found on the territory of Absheron for more than 50 years) - seven species, endangered (disappeared in several previously known localities) - 130 species, stable (found in previously known localities) - 209 species, dynamic (disappeared in previously known localities, but found in new localities) - 191 species, progressive (found in previously known localities and found in new localities) - 47 species. It is well known that for any region the adventive element of the flora is more dynamic than the native one. In total, we recorded 97 adventive species for the Absheron peninsula, of which 23 were new species for the flora of the region. We draw attention to the fact that since the beginning of the XIX century, the relative role of various sources of replenishment of the adventitious flora has changed. However, with the beginning of the new millennium, the contribution of railways to the formation of the advent component is noticeably decreasing. The number of new species entering the territory of the Absheron Peninsula by rail is radically decreasing. During the period covering 9 years (from 2012 to 2020), we were not able to find a single new adventive species that was intrude by rail. On the other hands, the activity of cultivated ornamental trees, shrubs and herbaceous plants became more clearly visible. There is a significant increase in the role landfills and wastelands in the formation of the adventive flora of the region.
Keywords: invasion, adventive species, flora dynamics, biodiversity, Absheron, Azerbaijan.

\section{INTRODUCTION}

The Absheron peninsula has long attracted the attention of florists. The floristic study of the peninsula probably began with the collections of C.A. Meyer in 18291830 years. Further research on Absheron took place in the immediate vicinity of the city of Baku. The first summarizing report on the flora of Absheron is "Flora of Absheron and South-East Shirvan steppe" which was published by P.V. Schwann-Gurian [1928]. This short guide for the identification of plants is a compilation of literature sources. The most important and noticeable stage in the study of the species diversity of plants on the Absheron peninsula was the monograph by I.I. Karyagin [1952] "Flora of Absheron". This key summary was written on the basis of field collections by the author himself, and the floristic work of other researchers was also taken into account. For over 70 years, this book has been the only guide to the flora of the peninsula. For such an impressive time period, a rich factual material has accumulated, which significantly corrects our knowledge of the territory under discussion. Numerous expeditions of the V.L. Komarov of the USSR Academy of Sciences and the Institute of Botany of the ANAS discovered many new localities and new taxa both in Absheron and throughout Azerbaijan. However, the study of flora comes down not only to the search for new species, but also to the confirmation of the growth of previously known ones in the composition of the flora. The last point was neglected by previous researchers. Among the reasons for the insufficient study of the modern flora of the Absheron Peninsula should be attributed: 1) a detailed study of the flora of the Absheron peninsula was not the main goal of both complex and special expeditions; 2) the routes and time frames of these expeditions excluded the possibility of detailed collection of herbarium in separate altitudinal belts, ecotopes and mountain ranges; 3 ) expeditionary work mainly covered, for the most part, the most easily accessible parts of the Absheron peninsula around the

${ }^{1}$ E-mail: zernov72@yandex.ru

Received 05 April 2021; Received in revised form 30 April 2021; Accepted 26 May 2021 
cities of Baku and Sumgait, while the most inaccessible territories remained unexplored.

The timeliness of a complete flora inventory is determined by the fact that flora monitoring has never been carried out, and the territory of the Absheron peninsula has undergone a serious anthropogenic transformation over the past decades. This is due to large-scale technogenic transformations of ecotopes during the development of oil fields and intensive construction of residential areas and technical and social infrastructure. This load calls into question the existence of many native stenotopic species. At the same time, fundamentally new habitats and conditions for biological invasions and expansions are emerging. All of the above encouraged us to undertake a comprehensive study of the current state of the flora of the Absheron peninsula [Zernov, Mirzayeva, 2021].

\section{MATERIAL AND METHODS}

The boundaries of the Absheron peninsula were adopted by us as well as in the book of I.I. Karyagin [1952]: from the northeast, east and southeast along the coast of the Caspian Sea; the western border runs along the meridian from the lower course of the river Sumgaitchay (in the north) to Mount Korgez (in the south); in the southwest, the border runs west of the Ag-Burun and Ilkhi-dag mountains, including the foothills of Gobustan.

The study of the flora of Absheron was carried out by the route method, in combination with the method of random samples. Due to the fact that the peninsula has a difficult relief, a variety of natural obstacles, a frequent change of ecotopes, a mosaic of vegetation cover and a diversity of phytocenoses, any study of the flora of mountainous territories cannot be conducted otherwise than by a combination of these methods [Programs ..., 1987]. The higher diversity and contrast of ecotopes in the mountains (in comparison with the plains) cause an increased spatial diversity of flora, including a faster spatial change of contrasting floristic situations. Hence the greatest justification for a continuous (and not selective) detailed survey of the flora of individual ridges and mountain nodes. All lithological varieties were examined for sufficient completeness of flora identification. In our understanding, a route is not only a trajectory of movement, but a certain examined local area to which it is tied (in the ideal case, a landscape section where all encountered species have been identified). The length of each route was about $3 \mathrm{~km}$. Advantages of the method are 1) the distribution of species over the territory is traced, it becomes possible to link to a specific area and compare with geological, geographical, historical, etc.; 2) the exact places of growth of rare species were obtained and reflected; 3 ) it becomes possible to compile a detailed description of the ecological confinement of the species in the studied local area, to identify its characteristic habitats, without referring to general data from the literature, and to reflect the specificity of this particular area; 4) routes are immediately identified where a relatively large number of species in general or a large number of rare plant species are recorded (key botanical areas where flora monitoring can be carried out in the future).

In accordance with the accepted methodology, field observations were carried out in the seasons of 20122020, at different times: early and late spring, summer, late summer and at some points in autumn.

To identify adventive and invasive species, olive plantations, oil field technical sites, old parks, lawns, separate sections of railways and highways, wastelands, dumps and garbage dumps of settlements and other anthropogenic habitats were examined. Similar surveys were carried out in the cities of Baku and Sumgait, as well as in large settlements.

In order to study the dynamics of flora, modern studies were repeated in detail and reliably studied in the past places.

Herbarium specimens collected during the research are stored in the Herbarium of the Institute of Botany of ANAS (BAK) and in the D. P. Syreyshchikov Herbarium of the Faculty of Biology of the Lomonosov Moscow State University (MW).

The volume of taxa is adopted in accordance with the taxonomic views of the authors, the nomenclature is given mainly in accordance with the World Flora Online database [http://www.worldfloraonline.org/], except for cases of discrepancy with the taxonomic position of the authors.

\section{RESULTS AND DISCUSSION}

The list of flora of the Absheron peninsula, according to our data, consist of 678 species. The flora of any district can be divided into two groups: native and adventive species.

Over 70 years, of the 599 species assigned to the native flora of Absheron, more than 180 (about one third) have significantly changed their distribution. Also, during this time, the flora was replenished with at least 24 native and 23 naturalized species on the territory of the distrcit, the appearance and composition of its vegetation cover changed significantly over a relatively 
short period in historical terms.

We did not include 206 species in the total number of species of native flora, which were indicated for Absheron by previous researchers, since we were unable to find these species in the localities recorded by the authors, [Zernov, Mirzayeva, 2021] and we could not find documentary evidence (herbarium specimens) that these species have ever been found in these habitats. For the same reasons, these species were excluded from the assessment of flora dynamics.

Of the species that we have included in the list, seven species have apparently disappeared. This group includes, mainly, ferns, noted in the wells of the village of Bilgah. We could not find a single well in this village and in other villages too. According to the residents of Bilgah, these wells were filled up in the 1990s, thus the habitats suitable for the growth of hygromorphic ferns in the arid climate of Absheron have disappeared. We also consider Eversmannia subspinosa (DC.) B. Fedtsch to have disappeared on the territory of Absheron. This species is indicated on the eastern dry slopes of the Yasamal valley in the environs Baku [Karyagin, 1952]. Our careful searches for this plant in the Yasamal valley were unsuccessful. Currently, active residential development is underway in the Yasamal valley and we have not found suitable habitats.

In our opinion, 130 species should be attributed to the endangered category, these are hardly noticeable plants, the lack of information about which can be explained by the fact that they are "visible" or data on their growth is insufficient for the final conclusion, but all previously known localities were examined by us. We include all species in this group, the collection of which has not been repeated after 1955 .

More than 130 native species have disappeared or are undoubtedly disappearing, while approximately 43 native species are progressing clearly. The number of endangered species is three times greater than the number of progressive ones, even if we do not take into account the "possibly endangered" species.

Among the endangered species, there are some doubts about the dynamics of the number for about $1 / 4$ of the species, among the progressive ones there are more of them, about $1 / 3$. This is due to the fact that now we can establish that a particular species is less common than it was indicated earlier. On the other hand, it is extremely difficult to prove that the species were really rare, and not ignored during the collection due to triviality.

The two largest groups form stable and dynamic species, each of which includes about $1 / 3$ of the total composition of the native flora. We classify 208 species as stable. These are the species that we found in the same localities where they were found 70 years ago and we could not find new localities.

We classify 191 species as dynamic species that disappeared in some areas, but appeared in others. Some of them have changed their habitats. Most of the dynamic species are annuals, including spring ephemers. The dynamism of ephemers in a geographical sense is somewhat arbitrary, i.e. annual plants have clearly expressed annual fluctuation in the number of individuals. This fluctuation leads to the fact that in some years the species may not be found in some habitats, and then reappear at the expense of the soil seed bank. The dynamic range of annual species is also associated with the peculiarities of the dispersion of their diaspores (seeds and fruits).

We classify 47 species as noticeably progressive (expansive) species. Expansions are probably associated with the creation of the Samur-Absheron channel on the territory of the Absheron peninsula. Almost all progressive species are associated with aquatic habitats that were absent before the creation of the irrigation system in 1934-1940.

We have noted 24 new native species: for the flora of the Eastern Caucasus - Lemna minor L.; for the flora of Azerbaijan - Rumex marschallianus Rchb., Cuscuta campestris Yunck.; for flora of the Absheron Peninsula Carex riparia Curt., Eleocharis quinqueflora (Hartmann) O. Schwarz, Eleocharis palustris (L.) Roem. et Schult., Ranunculus trichophyllus Chaix ex Vill., Sedum pallidum M. Bieb., Urospermum picroides (L.) Scop. ex F.W. Schmidt, Juncus articulatus L., Rosa canina L., Rubus candicans Weihe, Centaurium spicatum (L.) Fritsch, Potamogeton crispus L., Potamogeton pusillus L., Zannichellia pedunculata Rchb., Schoenoplectus litoralis (Schrad.) Palla, Cyperus pannonicus Jacquin, Lemna gibba L., Rumex palustris Sm., Ceratophyllum demersum L., Samolus valerandi L., Lycopus europaeus L., Serratula radiata (Waldst. et Kit.) M. Bieb. Their finding is due, on the one hand, to poor exploration of some areas of the region, on the other hand, to the ability of species to migrate at the present time (species do not "sit still" in place, they constantly change their ranges, (but it is not easy to observe). Apparently, many of identified species are progressive (expansive).

Adventive plants are a special component of the flora, different from its native part. Their appearance in the flora is associated with economic activities, as a 
result of which diaspores of alien plants are transferred to new areas outside the natural range. The fate of these new species in regional floras is different: in a number of places their share is significant and in terms of volume is comparable to that of the natural flora.

A total of 97 adventive species have been registered in Absheron, of which 23 are new species for the flora of the region: Lepidium didymum L., Fumaria capreolata L., Ruta graveolens L., Mentha spicata L., Glebionis coronaria (L.) Cass. ex Spach, Solanum elaeagnifolium Cav., Carex divulsa Stokes, Geranium albanum M. Bieb., Cardamine hirsuta L., Cannabis sativa L., Polycarpon tetraphyllum (L.) L., Oxalis corniculata L., Acalypha auctralis Krauss, Euphorbia maculata L., Euphorbia granulata Forssk., Eclipta prostrata (L.) L., Caesalpinia gilliesii (Hook.) D. Dietr., Trifolium pretense L., Lycium barbarum L., Datura inoxia Mill., Phytolacca americana L., Allium neapolitanum Cirillo., Chenopodium rubrum $\mathrm{L}$.

When defining the concept of "adventive flora", it is usually stated that these plant species penetrate into a particular territory as a result of economic activity or have spread with the help of humans from the primary or secondary range.

However, this definition is not operational, since the introducing process itself usually remains outside the scope of research. An exception is the activity of state services of phytosanitary control, which check goods when they cross the customs border. The work of these organizations has a number of significant limitations. Firstly, only part of the cargo, mainly for agricultural purposes is subject to inspection. Accidental contamination of vehicles, containers or packaging can be overlooked. Secondly, the ability to accurately identify plants by fruits and especially, seeds is difficult. Thirdly, the reports of the quarantine services are not available to public publication.

Thus, the adventive nature of the species has to be assessed by indirect signs. These features can be combined into several groups [Mayorov et al., 2012]:

- remoteness of the location from the main range of the species;

- novelty of the finding - the species has never been seen

in this area before;

- inconsistency of the ecological properties of the species with local conditions;

- confinement of growth areas to anthropogenic habitats

However, none of these signs can serve as accurate evidence of anthropogenic introduction of the species. In some cases, these characters may correspond to species expanding their range for natural reasons associated with fluctuations in numbers and climatic changes. Such expansive species sometimes cannot be distinguished from adventive species that invade a new territory [Zernov, Mirzayeva, 2013].

The adventive element of the flora of any region is more dynamic than the native one. It is constantly changing due to the introduction of new species, the naturalization of cultivated plants, and also as a result of the loss of previously introduced species from the flora.

The approaches to isolating the adventive element can be different. It is not uncommon for certain species to be found in natural conditions only in a part of the flora, while in the rest of them they behave like adventists.

At the beginning of the twentieth century, the special role of the cities of Baku and Sumgait in the formation of the adventive flora of the district is clearly traced. Due to the presence of railway stations and active transportation by rail, this role has been preserved for a long time. The leading role of railways remains almost until the end of the 20th century. At the beginning of the XXI century the relative role of different sources of replenishment of the adventive flora changes. The contribution of railways to the formation of the adventive component is decreasing. The number of new species introduced by rail is noticeably decreasing. For last nine years, we have not been able to find a single new adventive species, that was intrude by rail. As a result of the development, the frequency of occurrence of some adventive species associated with segetal habitats continues to decrease. On the other hands, the activity of cultivated ornamental trees, shrubs and herbaceous plants became more clearly visible. There is a significant increase in the role of dump sites and wastelands in the formation of the adventive flora of the peninsula.

\section{ACKNOWLEDGMENT}

The authors thank the director of the Institute of Botany of the ANAS, academician Valida M. Alizade for comprehensive support and financial assistance in the study.

\section{REFERENCES}

Zernov A.S., Mirzoeva Sh.N. (2013) New adventive species of flowering plants in the flora of the Absheron Peninsula. Proceedings of the Institute of Botany of the National Academy of Sciences of Azerbaijan, 33: 
10-14. [Зернов А.С., Мирзоева Ш.Н. (2013) Новые адвентивные виды цветковых растений во флоре Апшеронского полуострова. Труды Института ботаники НАН Азербайджана, 33: 10-14]

Zernov A.S., Mirzoeva Sh.N. (2021) Checklist of Apsheron flora. Ed. prof. V.G. Onipchenko and Acad. V.M. Alizade. Baku: 204 s. [Зернов A.С., Мирзоева Ш.Н. (2021) Чеклист флоры Апшерона. Под ред. проф. В.Г. Онипченко и акад. В.М. Ализаде. Баку: 204 с.]

Karyagin I. I. (1952) Flora of Absheron. Baku: Publishing house of the Academy of Sciences of the Azerbaijan SSR, 439 р. [Карягин И.И. (1952) Флора Апшерона. Баку: Изд-во АН АзССР. 439 c.]

Mayorov S.R., Bochkin V.D., Nasimovich Yu.A., Shcherbakov A.V. (2012) Adventure flora of Moscow and Moscow region. Moscow: T-in scientific. editions of КMК. 120 p. [Майоров C.P., Бочкин В.Д., Насимович Ю.А., Щербаков А.В. (2012) Адвентивная флора Москвы и Московской области. Москва: Т-во научн. изданий КМК. 120 c.]

Floristic research programs of varying degrees of detail (1987) Theoretical. and methodical. compare problems. floristry: Mat. II working. meeting. by compare floristry. Neringa, 1983. L.: Nauka, 219241. [Программы флористических исследований разной степени детальности. (1987) Теоретич. и методич. проблемы сравнит. флористики: Мат. II рабоч. совещ. по сравнит. флористике. Неринга, 1983. Л.: Наука, 219-241]

Schwann-Gurijsky P.V. (1928) Flora of Absheron and S-E. Shirvan steppe (a short guide to the identification of plants). Baku: AZGIZ, 132 p. [Шванн-Гурийский П.В. (1928) Флора Апшерона и Ю.-В. Ширванской степи (краткое пособие по определению растений). Баку: АЗГИЗ, 132 с.]

World Flora Online. An Online Flora of All Known Plants. http://www.worldfloraonline.org/

Karimov V., Yusufov E., Murtazaliev R. (2016) New species of vascular plants from Azerbaijan for the flora of the Caucasus. Bot. jour. 101(5): 592-594. [Каримов В., Юсуфов Е., Муртазалиев Р. (2016) Новые для флоры Кавказа виды сосудистых растений из Азербайджана. Бот. журн. 101(5) 592-594]

Zernov A.S., Mirzayeva Sh.N. (2016) Solanum elaeagnifolium Cavara, a new invasive species in the Caucasus. Wulfenia, 23: 253-256.
Mirzayeva Sh.N., Zernov A.S., 2017, The new plants of Absheron peninsula. Proceedings of the Institute of Botany, ANAS, XXXVII: 75-80.

Witt A., Luke Q. (2017) Guide to the naturalized and invasive plants of Eastern Africa. CABI, Nairobi, Kenya, $601 \mathrm{pp}$.

Zernov A.S. (2003) On the adventive flora of the Northwest Caucasus. Problems of studying the adventive and synanthropic flora in the CIS. Scientific materials. conf. regions Moscow-Tula: 44-45. A.S. (2006) [Зернов А.С. (2003) Об адвентивной флоре Северо-Западного Кавказа. Проблемы изучения адвентивной и синантропной флоры в СНГ. Материалы научн. конф. регионах Москва-Тула: 44-45. A.C. (2006)]

\section{Abşeron yarımadasının bitki müxtəlifliyi}

\author{
Aleksandr S. Zernov \\ M.V. Lomonosov adına Moskva Dövlat Universiteti, Biologiya Fakültasi, \\ Leninskie Gory, 1-12, Moskva 119991, Rusiya
}

\section{Şəhla N. Mirzayeva}

AMEA Botanika İnstitutu, Badamdar şossesi 40, Bakl, AZ1004, Azərbaycan

Məqalədə Abşeron yarımadasının florasının öyrənilməsinin nəticələri müzakirə olunnur. 70 ildə növ tərkibinin dinamikası nəzərdən keçirilir. 1952-ci ildə İ.İ.Karyagin tərəfindən qeyd olunmuş növlərdən 206nın mövcudluğunu təsdiq etmək mümkün olmamışdır. Abşeron yarımadasının flora siyahısına 678 növ daxildir ki, bunlardan 599 növ yerli flora kimi təsnif edilir. Areallarının dinamikasının inkişaf istiqamətinə görə yerli flora növləri 5 qrupa ayrılmışdır. İtmiş - 7 növ (50 ildən çoxdur ki Abşeron ərazisində tapılmayıb), itmə təhlükəsində olan - 130 növ (əvvəllər məlum olan bir neçə ərazidə yoxa çıxıb), sabit - 208 növ (əvvəllər məlum olan ərazilərdə rast gəlinib), dinamik - 191 növ (əvvəllər məlum olan ərazilərdə yoxa çıxıb, yeni ərazilərdə rast gəlinib), inkişafda olan - 47 növ (əvvəllər məlum olan ərazilərdə və yeni ərazilərdə rast gəlinib). Hər hans1 bir bölgənin florasının adventiv elementi, yerlidən daha dinamikdir. Abşeronda cəmi 97 adventiv növ qeydə alınmışdır ki, bunlardan 23-ü bölgənin florası üçün yeni növdür. XIX əsrin əvvəlindən bəri adventiv floranın növlərlə zənginləşdirilməsində müxtəlif mənbələrin nisbi rolu dəyişib. Lakin, yeni minilliyin başlanğıcı ilə dəmir yollarının adventiv komponentinin formalaşmasına təsiri nəzərəçarpacaq dərəcədə azalır. Abşeron yarımadasının ərazisində dəmir yolu ilə gətirilən yeni növlərin sayı kəskin şəkildə azalıb. Doqquz (2012-2020) ildə dəmir yolu ilə gətirilən heç 
bir yeni növə rast gəlinməmişdir. Digər tərəfdən dekorativ ağacların, kolların və ot bitkilərinin becərilməsi daha aydın şəkildə özünü göstərir. Bölgənin adventiv florasının formalaşmasında zibilliklərin vo tullantı sahələrinin də rolunda ciddi artım müşahidə olunur.

Açar sözlor: invaziya, adventiv növlar, flora dinamikast, biomüxtaliflik, Abşeron, Azərbaycan

Разнообразие растений Апшеронского полуострова

\section{Александр С. Зернов}

Биологический факультет, МГУ им. М.В. Ломоносова, Ленинские Горы, 1-12, Москва 119991, Россия

\section{Шахла Н. Мирзаева}

Институт Ботаники НАН Азербайджана, Бадамдарское шоссе 40 Баку, АZ1004, Азербайджан

В этой статье мы обсуждаем результаты изучения флоры Апшеронского полуострова. Рассмотрена динамика видового состава за последние 70 лет. Нам не удалось найти 206 видов в местообитаниях, ранее зафиксированных Карягиным в 1952 году. Мы включили 678 видов в список флоры Апшеронского полуострова, из которых 599 видов были отнесены к аборигенной флоре. В соответствии с направлением динамики их местообитаний мы выделяем пять групп видов аборигенной флоры: Исчезнувшие (не встречающиеся на территории Апшерона более 50 лет) - семь видов, находящиеся под угрозой исчезновения (исчезнувшие в нескольких ранее извест- ных местонахождениях) - 130 видов, стабильные (обнаружены в ранее известных местонахождениях) - 209 видов, динамические (исчезли в ранее известных местонахождениях, но обнаружены в новых местонахождениях) - 191 вид, прогрессивные (обнаружены в ранее известных местонахождениях и обнаружены в новых местонахождениях) - 47 видов. Как известно, для любого региона адвентивный элемент растительного мира более динамичен, чем нативный. Всего на Апшеронском полуострове зарегистрировано 97 адвентивных видов, из них 23 новых вида для флоры региона. Обращаем внимание на то, что с начала XIX века относительная роль различных источников пополнения изменилась придаточная флора. Однако с началом нового тысячелетия вклад железных дорог в формирование адвентивной составляющей заметно снижается, резко сокращается количество новых видов, попадающих на территорию Апшеронского полуострова по железной дороге. За 9 лет (с 2012 по 2020 гг.) Нам не удалось найти ни одного нового адвентивного вида, вторгшегося по железной дороге. С другой стороны, деятельность культурных декоративных деревьев, кустарников и травянистых растений стала более заметной. Значительно возрастает роль свалок и пустырей в формировании адвентивной флоры региона.

Ключевые слова: инвазия, адвентивные виды, динамика флоры, биоразнообразие, Апшерон, Азербайджан 